\title{
一業界情勢—
}

\section{わが国染料エ業の概 況}

\section{山口四郎* \\ Shiro Yamaguchi}

\section{I. 最近の染料需給の推移}

前回本誌（Vol. 13 No. 1, 1955）飞昭和 29 年 9 月頃 迄のことを述べたので今回は主にその以後のことについ て記す。

昭和 28 年秋半から約 1 ケ年余の緊縮政策による篅要 減退の後を受けて昭和 30 年は一般に輸出の伸長も手伝 つて約 20,000t の生産に回復した。

染料種属別に見ると最近生産が特に増加しているもの としてスレン染料, ナフトール染料, セリトン系染料, 螢光增白剤等が注目される(第 2 表参照)。尚更に直接, 酸性その他の染料種属内の品種についても大体の傾向と して堅牢度の高い染料への要求が漸次增加していること は事実でありこれは翰出面にも同じ要求が現れており世 界の染料に対する要求の傾向の一つと見るべきである。

第 1 表 国産染料需給の推移 (単位: $\mathbf{t}$ )

\begin{tabular}{|c|c|c|c|c|}
\hline 年 & 月 & 生 産 & 出 荷 & 在 庫 \\
\hline \multirow[t]{6}{*}{ 昭和 29} & 年 7 & 1,013 & 1,066 & 3,129 \\
\hline & 8 & 1,115 & 1,386 & 2,860 \\
\hline & 9 & 1,434 & 1,560 & 2,725 \\
\hline & 10 & 1,668 & 1,804 & 2,562 \\
\hline & 11 & 1,574 & 1,671 & 2,380 \\
\hline & 12 & 1,555 & 1,667 & 2,232 \\
\hline \multirow[t]{12}{*}{ 昭和 30} & 年 1 & 1,505 & 1,507 & 2,195 \\
\hline & 2 & 1,564 & 1,438 & 2,287 \\
\hline & 3 & 1,548 & 1,538 & 2,259 \\
\hline & 4 & 1,633 & 1,515 & 2,348 \\
\hline & 5 & 1,733 & 1,626 & 2,428 \\
\hline & 6 & 1,740 & 1,582 & 2,561 \\
\hline & 7 & 1,543 & 1,517 & 2,566 \\
\hline & 8 & 1,696 & 1,775 & 2,463 \\
\hline & 9 & 1,677 & 1,779 & 2,333 \\
\hline & 10 & 1,830 & 1,789 & 2,344 \\
\hline & 11 & 1,776 & 1,777 & 2,312 \\
\hline & 12 & 1,699 & 1,800 & 2,142 \\
\hline
\end{tabular}

*化成品工業協会 (中央区日本橋本町 2-6)

\section{II. 染料の輸出情況}

染料が輸出繊維加工として輸出される以外に染料自体 の輸出も染料工業維持のため特に重要である。戦前の輸 出が全生産量飞対し約 30〜 40\% であるに対し現在は 10〜12\%程度になつて居り，中国，ホンコン，インド, パキスタン，ブラジルどが最も多い（第 4 琭参照）。

染料種属別についてはスレン染料，ナフトール染料等 が最近特に增加していることも一つの特微である（第 3 表参照)。

\section{III. 染料の輸入情況}

最近の輸入染料の概況は第 5 趇の様である。䡕入国は ドイッ，スイスこれにつぎアメリカが多く樰属別に見 ると直接，酸性，酸性媒染染料の数量が最も多いが，国 第 2 表 種属別染料生産統計 (単位: $t$ )

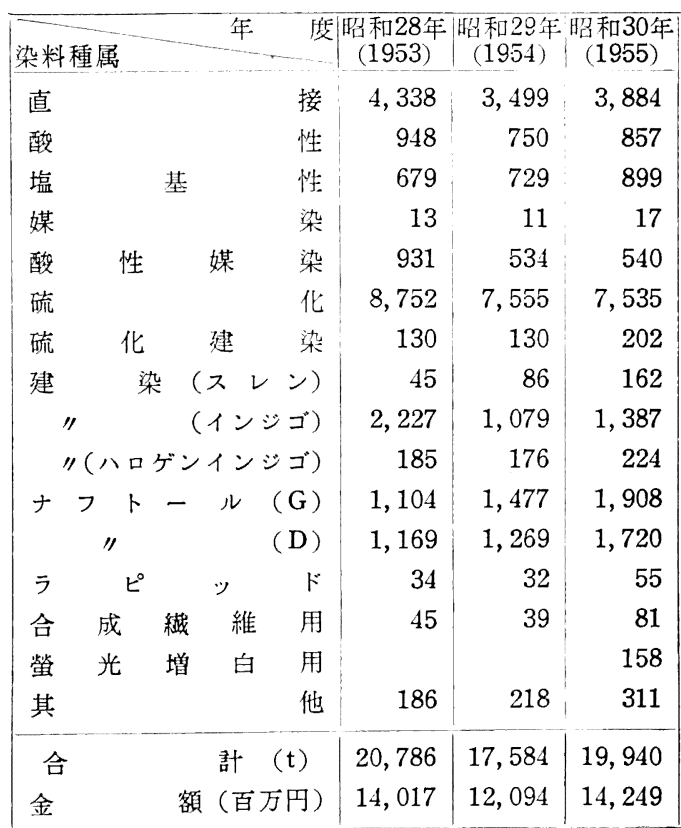

（注）1. 数量住 $\mathrm{t}$ 以下 4 唅 5 入

2. 年度心曆年度 
第 3 表 染料輸出統計 (種属別) (単位: $t$ )

\begin{tabular}{|c|c|c|c|}
\hline 染料種属 & $\begin{array}{c}\text { 昭和 } 28 \text { 年 } \\
(1953)\end{array}$ & \multicolumn{2}{|c|}{\begin{tabular}{|c|c|} 
昭和29年 \\
$(1954)$
\end{tabular} \mid $\begin{array}{c}\text { 和30年 } \\
(1955)\end{array}$} \\
\hline 直 & 285 & 198 & 197 \\
\hline 酸 & 37 & 24 & 24 \\
\hline 基 & 33 & 89 & 188 \\
\hline 媒 & 1 & 一 & - \\
\hline 性 媒 染 & 4 & 26 & 13 \\
\hline 硫 & 1,279 & 965 & 1,013 \\
\hline 化 建 染 & 1 & 4 & 8 \\
\hline 建 染 (スレン) & 22 & 36 & 69 \\
\hline " (ハロゲンインジゴ) & 1 & 5 & 28 \\
\hline 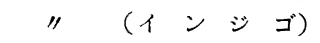 & 355 & $※$ & 2 \\
\hline 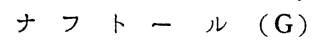 & 11 & 229 & 324 \\
\hline "l (D) & 58 & 216 & 326 \\
\hline ピ ッ & 7 & 18 & 12 \\
\hline 合 繊 用(セリトン系) & 一 & 1 & $\%$ \\
\hline 烜 光 增 白 & ॥ & 10 & 26 \\
\hline 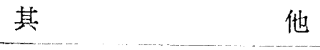 & $\%$ & 10 & 17 \\
\hline 計 $(\mathrm{t})$ & 2,094 & 1,821 & 2,247 \\
\hline 額（百万円） & 816 & 1,012 & 1,461 \\
\hline
\end{tabular}

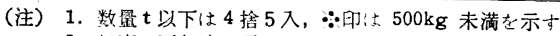
2. 年度:暦年度を示与

第 4 表 染料翰出統計（地域別）（単位 $\mathbf{t}$ )

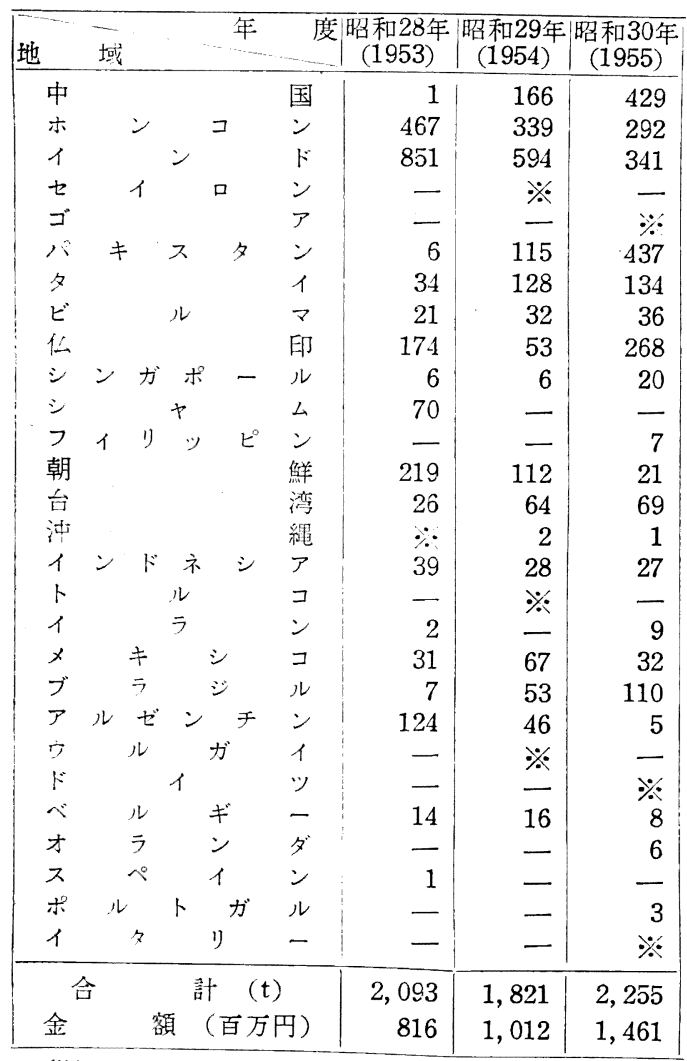

（注） 1. 数量 $\mathrm{t}$ 以下は 4 唅 5 入，泪印声 $500 \mathrm{~kg}$ 末満を示す 2. 年度は雗年を示与
第 5 表 輸入染料統計 (単位 $t$ )

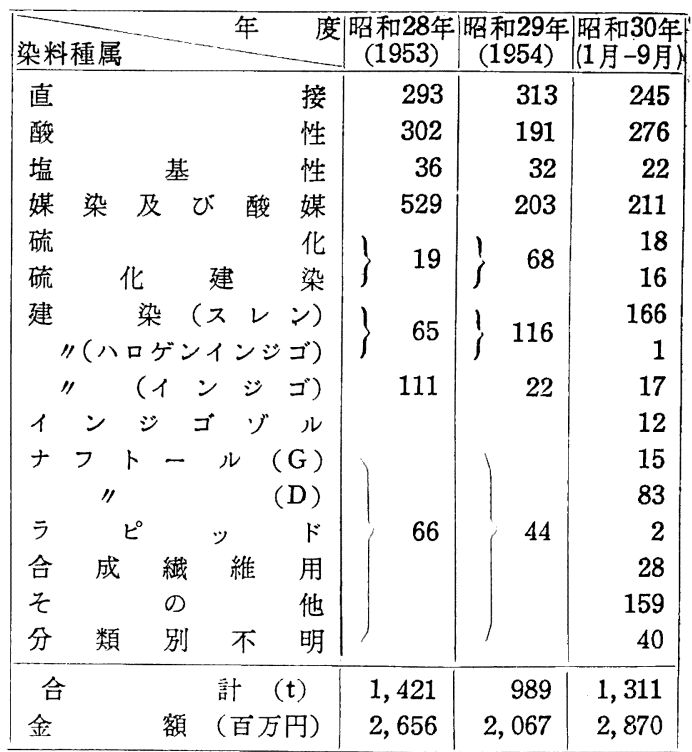

（注） 1. 数量 $\mathrm{t} \mathrm{t}$ 以下, 金額は 100 万円以下 4 捨 5 入 2. 年度は暦年度

第 6 表 中間物の輸出 (昭和 30 年 1 月 12月) (A) 品 目 別

(単位: $t$ )

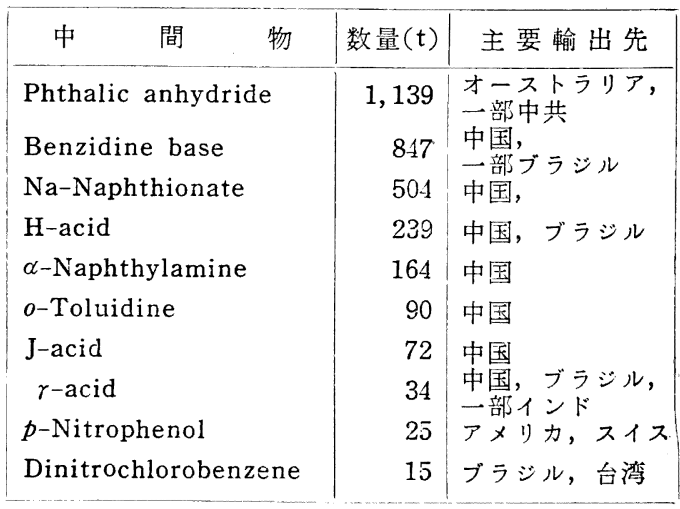

(B) 輸出先 別

\begin{tabular}{|lrr|r|r|}
\hline 国 & & 別 & 数量 $(\mathrm{t})$ \\
\hline 中 & & & 国 & 1,992 \\
オーストラリア & 1,023 \\
ホ & ン & コ & ン & 43 \\
ブ & ラ & シ & ル & 83 \\
台 & & & 湾 & 17 \\
ア & & リ & カ & 15 \\
ス & イ & & ス & 13 \\
\hline
\end{tabular}

（注） 1 . 年間数量合計 $10 \mathrm{t}$ 以上に達し たものだけを拍 けた。

2. 数量は $\mathrm{t}$ 以下 は 4 捨 5 入したc

内消費量飞対する輸入染料の比率はスレン染料, 酸性, 酸 
性媒染染料が極めて大きい。その中でも特にスレン染料 の場合には国産数量をも上迴る数字を示していることは 今後の染料工業対策として考庶すへき問題を与えている。 㡏入染料の品種については国産と競合するものを極めて 多量飞含んでいることは，他の一般商品にもその傾向が 多く見られることであり，国産染料の使用を更に徹底す る様にしたい。もし品質に不充分な点がある場合にはそ の改善は勿論であるが特に Service Station の機能を

一層強化することが是非共必要であろう。

\section{IV. 中間物の輸出}

中国，インドを始め工業未開国が工業立国への努力が 旺盛になり，生産が開始されれば自国品でまかなわんと する考えは戦後一般の傾向でありわが国輸出染料が漸次 高級品種へ移行するのもその現れの一つであり，これと 共に一方中間物の輸出が急速に進展し，わが国染料工業 界にとつて生きる道であり助長すべきことである。特に 一昨年頃から中国への中間物の輸出は急速に增加した。

\section{一交献紹介一}

1. 染料及び中間物, 2 . 染色化学, 3. 石油化学, 4. 高分子化学, 5 . その他, の 5 部門とし，下記要領で抄録する。5.は特別の制限を設けず随時紹介する。

(i) 抄録雑誌 J.Am. Chem. Soc., J. Chem. Soc., Chem. Ber., Helv. chim. Acta, Ind. Eng. Chem., J. Soc. Dyers \& Colourists, Melliand Textilber., Am. Dyestuff Reptr., J. Textile Inst., J. Polymer Sci., Makromol. Chem., J. Phys. Chem., Trans. Faraday. Soc., Proc. Roy. Soc., Pet. Ref., Chem. Eng. Progress,

(ii) 抄録方法 1〜4 部門飞関連ある上記雑誌の文献は,なるへく網羅主義で抄録し， 特に目新しい文献は其他の雑誌からも追加紹介する。

\section{1. 染料及び中間物}

求核置換反応におけるニトロ基の影蠁 ニトロ基の o-，又は $p$-位にある八ロゲンは求核置換をうけ易いこ とは良く知られている。クロルニトロベンゼンとピペリ シンとの反㐫で方，o-体が $p$-体よりも反応性が大きい。

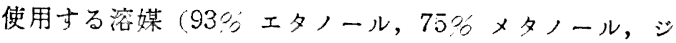
オキサン）の極性が大きくなるにともない，溶媒和によ つて反応速度は大となる。ことに $p$-体において此の影 響が著しい。これらの結果を，反応が $\mathrm{S}_{\mathrm{N} 2}$ 型で進行す るものとして漫移状態に拈ける權造について考察を進め ている。

[J. F. Bunnett, R.J. Morath: J. Am. Chem. Soc. 17, 5051 (1955)] (飛田満彦)

求核置換反応におけるカルボキシラート基の影響 4-クロル-3-ニトロ安息香酸ナトリウム, 2-クロル-5-二 トロ安息否酸ナトリウムのピペリシンとの反応速度恒 数を, $o$-クロル ニトロベンゼン, p-クロル ニトロベン ゼンの場合と夫々比較して見ると, カルボキシラート基 (-COO-) によつて反応が一層容易となり，o-体におい てこの効果が大きいことがわかる。活性化エネルギー, 活 性化エントロピーについて見ると, カルボキシラート基 の効果は活性化エントロピーの增加によるものである。 従つて, ○ーカルボキシラート基の酸萦とピペリシンの窒
素 $\left(\mathrm{N}^{\delta+}\right)$ との間の静電爻的な相互作用が存在すると考 えられる。

[J. F. Bunnett, R. J. Morath, T. Okamoto: J. Am. Chem. Soc. 71, 5055 (1955)]（我田満彦）

Meerwein 反応の銅触媒 Meerwein 反応は, 芳 香族ジアゾニウムハロゲン化物と脂肪族不飽和化合物と を銅触媒の存在下で反応せしめ， $\alpha$-ハロゲンー $\beta$-フェニ ルアルカン又はアルケンを作る反応である。従来この反 応には塩化第二鉰が用いられていたが，著者の研究によ れば，塩化第二銅は共存するア七トンにより

$2 \mathrm{CuCl}_{2}+\mathrm{CH}_{3} \mathrm{COCH}_{3} \rightarrow$

$2 \mathrm{CuCl}+\mathrm{ClCH}_{2} \mathrm{COCH}_{3}+\mathrm{HCl}$

の如く䢱元される。かくして生成した塩化第一銅はシァ ゾニウム塩分解の強力な触媒である。オレフィンが存在 すれば，Sandmeyer 反応に先えじて Meerwein 反応 がおこる。

$$
\mathrm{ArN}_{2}{ }^{+} \mathrm{Cl}^{-}+>\mathrm{C}=\mathrm{C}<\stackrel{\mathrm{CuCl}}{\longrightarrow} \underset{\mathrm{Ar}-\mathrm{C}-\mathrm{C}-\mathrm{Cl}}{\mathrm{I}}
$$

従つて, 該反応の触媒作用は第二鉰が有するのでなく, 第一銅によるものである。塩化第一鉰を使用した場合に もアセトンは存在した方がよが，必らずしも必要とし ない。[J. K.Kochi : J. Am. Chem. Soc. 17, 5090(1955)] (飛田満彦) 